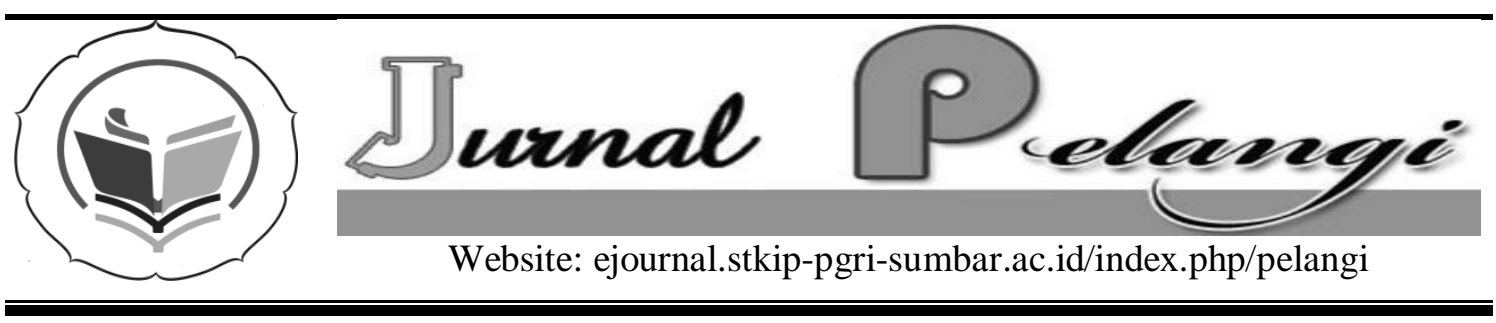

\title{
PENGGUNAAN TEKA-TEKI SILANG SEBAGAI SEBAGAI STRATEGI PENGULANGAN DALAM MENINGKATKAN PEMAHAMAN KONSEP MATEMATIKA SISWA SMA KELAS XI IPS
}

\author{
Sofia Edriati, Siskha Handayani, Nur Puspita Sari \\ STKIP PGRI sumatera Barat \\ sofiaedriati81@gmail.com
}

\section{INFO ARTIKEL}

\section{Diterima:}

26 Maret 2017

Direview:

8 Mei 2017

Disetujui:

13 Juni 2017

Kata Kunci:

Strategi Pengulangan, Teka Teki Silang,

Pemahaman Konsep matematika

\section{Keywords:}

Reviewing Strategy, Crossword Puzzle, Understanding of mathematical concept

\begin{abstract}
Abstrak
Penelitian ini bertujuan untuk mengetahui apakah pemahaman konsep matematika siswa dengan menerapkan strategi tekateki silang lebih baik daripada pemahaman konsep matematika siswa dengan menerapkan pembelajaran konvensional. Penelitian eksperimen ini menggunakan rancangan random terhadap subjek. Populasi penelitian adalah seluruh siswa kelas XI IPS salah satu SMA di Sijunjung. Data dikumpulkan melalui tes dengan instrumen tes berbentuk uraian. Data dianalisis menggunakan uji t. Berdasarkan hasil analisis data dapat disimpulkan bahwa pemahaman konsep matematika siswa dengan menerapkan strategi teka-teki silang lebih baik daripada pemahaman konsep matematika siswa dengan menerapkan pembelajaran konvensional.

Abstract
This study aims to determine the understanding of
mathematical concept by applying crossword puzzle strategy
better than the understanding of mathematical concepts by
applying conventional learning. This experimental study uses
random to the subject design. The study population is all
students of class XI IPS one of SMA in Sijunjung. data through
tests with test instuments. Data were analyzed using t test.
Based on the results of data analysis can be concluded by
considering the understanding of mathematical concepts by
applying crossword puzzles strategy better than the
understanding of mathematical concepts by applying
conventional learning.
\end{abstract}

\section{PENDAHULUAN}

Matematika merupakan salah satu cabang ilmu pengetahuan yang memegang peranan penting dalam kehidupan manusia. Hal ini terlihat dari penggunaan ilmu matematika dalam memecahkan masalah yang terjadi pada kehidupan sehari-hari. Pembelajaran 
matematika dapat melatih manusia berpikir secara logis, analitis, sistematis, kritis dan kreatif. Selain itu, matematika juga diperlukan untuk membantu memahami bidang studi lain seperti fisika, kimia, arsitektur, geografi dan ekonomi. Besarnya peran matematika tersebut menjadikan pelajaran matematika dipelajari secara luas dan dipahami secara mendasar mulai dari jenjang pendidikan dasar, pendidikan menengah sampai ke perguruan tinggi.

Matematika mempunyai peranan yang penting, sehingga siswa harus menguasai berbagai kemampuan. Depdiknas (2004) dalam Shadiq (2009: 13) menyatakan "Tiga aspek kemampuan yang harus dikuasai oleh siswa dalam mempelajari matematika yaitu pemahaman konsep, penalaran dan komunikasi, serta pemecahan masalah". Berdasarkan kutipan tersebut, salah satu kemampuan yang harus dikuasai siswa adalah pemahaman konsep.

Pemahaman konsep matematis yang baik bagi siswa sangatlah penting, karena untuk memahami konsep yang baru diperlukan prasyarat pemahaman konsep sebelumnya. Pemahaman terhadap materi pada pembelajaran matematika, tidak terlepas dari pemahaman konsep yang baik dari siswa tersebut. Jika semakin baik pemahaman konsep siswa, maka semakin tinggi pula tingkat keberhasilan siswa dalam pencapaian tujuan pembelajaran matematis siswa.

Usaha yang dilakukan oleh guru harus didukung oleh usaha dari siswa itu sendiri. Siswa harus mampu bersikap aktif dan kreatif agar pembelajaran matematika yang diberikan oleh guru dapat membentuk pemahaman konsep yang baik. Guru juga harus memberikan motivasi dan stimulus yang kuat guna mendorong siswa belajar menyelesaikan masalah yang timbul pada proses pembelajaran. Guru memberikan kesempatan siswa untuk belajar mandiri melalui kegiatan mengamati, menyelidiki, dan memecahkan masalah secara mandiri, sehingga siswa akan terlatih untuk berpartisipasi secara aktif dalam pembelajaran, mulai dari aktif bertanya sampai aktif dalam menjelaskan materi kepada temannya. Dengan demikian potensi yang dimiliki siswa akan berkembang.

Menurut Silberman (2009: 247) Teka Teki Silang termasuk dalam reviewing strategi (strategi pengulangan). Strategi teka teki silang berhubungan dengan cara-cara untuk mengingat kembali apa yang telah mereka pelajari dan pengujian kemampuan serta pengetahuan yang telah mereka peroleh. Khalilullah (2012:15) menyatakan bahwa teka teki silang berfungsi membangunkan sarafsaraf otak yang memberi efek menyegarkan ingatan sehingga fungsi kerja otak kembali optimal karena otak dibiasakan untuk terus belajar dengan santai.

Langkah-langkah strategi teka teki silang yang diungkapkan Silberman (2013:246) adalah:

1. Langkah pertama adalah mencurahkan gagasan, beberapa istilah atau nama-nama kunci yang berkaitan dengan pelajaran studi yang telah anda selesaikan.

2. Susunlah teka teki silang sederhana, yang mencakup item-item sebanyak yang anda dapat. Hitamkan kotakkotak yang tidak anda perlukan. (catatan: jika terlalu sulit untuk membuat teka teki silang, diselingi dengan item-item yang menyenangkan yang tidak berkaitan dengan pelajaran).

3. Buatlah contoh-contoh item-item silang, gunakan diantara macammacam berikut ini: definisi pendek ("tes yang digunakan untuk menentukan reliabilitas”), kategori 
yang sesuai dengan item ("jenis gas"), contoh ("frase a pleasant peace adalah contoh untuk ini), lawan kata ("lawan dari demokrasi")

4. Bagikan teka teki kepada peserta didik, baik secara individual maupun secara tim.

5. Tentukan batasan waktu. Serahkan hadiah kepada individu atau tim dengan benda yang paling konkret.

Pemahaman konsep matematika merupakan salah satu tujuan dari pembelajaran matematika. Menurut Shadiq (2009:13) "Pemahaman konsep berarti siswa mampu mendefenisikan konsep, mengidentifikasi dan memberi contoh atau bukan contoh dari konsep". Berdasarkan pengertian di atas, maka kemampuan pemahaman konsep adalah kecakapan atau kesanggupan dalam memahami ide-ide atau pokok penting dalam suatu materi yang telah dipelajari dan memberikan contoh atau bukan contoh dari konsep tersebut. Melalui pemahaman konsep kita akan mampu mengadakan analisis terhadap permasalahan untuk kemudian ditransformasikan ke dalam model dan bentuk persamaan matematika, baru kemampuan menghitung diperlukan.

Pemahaman konsep matematis dalam pembelajaran memberikan pengertian bahwa materi-materi yang diajarkan kepada siswa bukan hanya sebagai hafalan, namun dengan pemahaman siswa dapat lebih mengerti akan konsep materi pelajaran itu sendiri. Jadi dapat disimpulkan bahwa belajar konsep merupakan salah satu cara belajar dengan pemahaman yang mendalam. Dengan belajar melalui pemahaman konsep maka seorang siswa akan lebih mudah menerapkannya dalam kehidupan sehari-hari.

Indikator yang menunjukkan pemahaman konsep dalam Shadiq (2009:13) antara lain adalah:
1. Menyatakan ulang sebuah konsep,

2. Mengklasifikasi objek-objek menurut sifat-sifat tertentu (sesuai dengan konsepnya),

3. Memberi contoh dan non contoh dari konsep,

4. Menyajikan konsep dalam berbagai bentuk representasi matematis,

5. Mengembangkan syarat perlu atau syarat cukup suatu konsep, dan

6. Mengaplikasikan konsep atau algoritma pemecahan masalah.

Berdasarkan indikator di atas dapat disimpulkan bahwa seorang siswa dikatakan telah memahami konsep apabila mampu menyatakan ulang konsep, mampu mengklasifikasikan objek menurut sifat-sifat tertentu sesuai dengan konsepnya, mampu memberikan contoh dan non contoh dari konsep tersebut, menyajikan konsep dalam bentuk representasi matematis, mengembangkan syarat perlu atau syarat cukup suatu konsep, memilih prosedur tertentu dan mampu mengaplikasikan konsep ke pemecahan masalah.

Suherman (2003: 203) "Metode ekspositori merupakan metode pembelajaran dimana dominasi guru banyak berkurang karena tidak terus menerus bicara". Guru berbicara pada awal pelajaran yaitu menerangkan materi serta contoh soal dan pada waktu-waktu yang diperlukan saja. Pada metode ini siswa tidak hanya mendengar dan membuat catatan. Siswa juga membuat latihan dan bertanya kalau tidak dimengerti. Guru juga dapat memeriksa pekerjaan siswa secara individual dan menjelaskan lagi kepada siswa secara individual. Berdasarkan uraian di atas, penelitian ini bertujuan untuk mengetahui apakah pemahaman konsep matematika siswa dengan menerapkan strategi Teka Teki Silang lebih baik daripada pemahaman konsep matematika 
siswa dengan menerapkan pembelajaran konvensional.

\section{METODE PENELITIAN}

Penelitian eksperimen ini menggunakan rancangan random terhadap subjek. Populasi pada penelitian ini adalah seluruh siswa kelas XI IPS salah satu SMA di Sijunjung Tahun pelajaran 2016/2017. Populasi berjumlah 42 orang siswa. Karena populasi mempunyai kesamaan rata-rata maka pengambilan kelas eksperimen dan kelas kontrol dilakukan secara acak. Alat pengumpul data yang digunakan berupa tes akhir belajar yang memuat indikator pemahaman konsep. Soal tes akhir dibuat dalam bentuk esai yang disesuaikan dengan konsep materi yang telah dipelajari. Teknik pengumpulan data penelitian dilakukan dengan cara memberikan tes akhir kepada siswa setelah diberikan perlakuan. Data hasil tes akhir dianalisis dengan menggunakan uji t dengan rumus:

$$
\begin{gathered}
\mathrm{t}=\frac{\bar{x}_{1}-\bar{x}_{2}}{S \sqrt{\frac{1}{n_{1}}+\frac{1}{n_{2}}}} \\
\text { dengan } \mathrm{S}=\sqrt{\frac{\left(n_{1}-1\right) S_{1}^{2}+\left(n_{2}-1\right) S_{2}^{2}}{n_{1}+n_{2}-2}}
\end{gathered}
$$

$\bar{x}_{1}=$ Nilai rata-rata kelas eksperimen

$\bar{x}_{2}=$ Nilai Rata-rata kelas kontrol

$n_{1}=$ Jumlah siswa kelas eksperimen

$n_{2}=$ Jumlah siswa kelas kontrol

$S_{1}^{2}=$ Variansi pemahaman konsep kelas eksperimen

$S_{2}^{2}=$ Variansi pemahaman konsep kelas kontrol

$\mathrm{S}=$ Simpangan baku gabungan

Kriteria pengujian adalah Terima $H_{0}$ jika $t_{\text {hitung }}<t_{\text {tabel }}$ dengan derajat kebebasan $(\mathrm{dk})=\left(n_{1}+n_{2}-2\right)$ selain itu $H_{0}$ ditolak.

\section{HASIL DAN PEMBAHASAN}

Berdasarkan penelitian yang telah dilakukan diperoleh data hasil tes akhir yang disajikan pada Tabel 1. Hasil pengujian dengan uji $t$ satu pihak diperoleh $t_{\text {hitung }}=0,97$ dan $t_{(1-\alpha)}=$ 0,5 . Dengan demikian dapat disimpulkan bahwa pemahaman konsep matematika siswa dengan penerapan strategi tekateki silang lebih baik daripada pemahaman konsep matematika siswa dengan pembelajaran konvensional.

dimana :

\section{Tabel 1. Deskripsi Hasil Tes Akhir Kelas Sampel}

\begin{tabular}{|c|c|c|c|c|c|}
\hline $\begin{array}{c}\text { Kelas } \\
\text { Sampel }\end{array}$ & $\begin{array}{c}\text { Jumlah Siswa yang } \\
\text { Mengikuti Tes Akhir }\end{array}$ & $\overline{\boldsymbol{X}}$ & $\mathbf{S}$ & $\boldsymbol{X}_{\text {maks }}$ & $\boldsymbol{X}_{\text {min }}$ \\
\hline Eksperimen & 21 & 68,81 & 20,64 & 94 & 28 \\
\hline Kontrol & 21 & 54,19 & 20,89 & 83 & 14 \\
\hline
\end{tabular}

Pemahaman konsep matematis merupakan salah satu aspek dari hasil belajar. Pada penelitian ini indikator pemahaman konsep yang digunakan adalah Mengklasifikasi objek-objek menurut sifat-sifat tertentu (sesuai dengan konsepnya), mengaplikasikan konsep atau algoritma ke dalam pemecahan masalah, dan juga mampu menyajikan dalam berbagai bentuk 
representasi matematis sesuai dengan konsepnya.

Pada tahap pengulangan materi, guru memberikan lembar teka-teki silang pada setiap siswa. teka-teki silang tersebut berisikan pertanyaan dan kotak kosong sebagai tempat menuliskan jawaban. Pada pertemuan pertama siswa mengisi teka-teki silang membutuhkan waktu yang cukup lama, karena siswa harus merubah posisi dari duduk berkelompok menjadi duduk sendirisendiri. Teka-teki silang pada pertemuan pertama terlihat pada Gambar 1.

Guru telah menjelaskan kepada siswa tentang cara pengisian jawaban pada teka-teki silang, siswa sudah bisa mengisi teka-teki silang tetapi siswa terfokus pada isi teka-teki silangnya saja. Hal tersebut terlihat setelah dicek lembar jawaban siswa karena terburu-buru mencari isi dari teka-teki silang jawaban yang ditulis siswa tidak jelas dan siswa

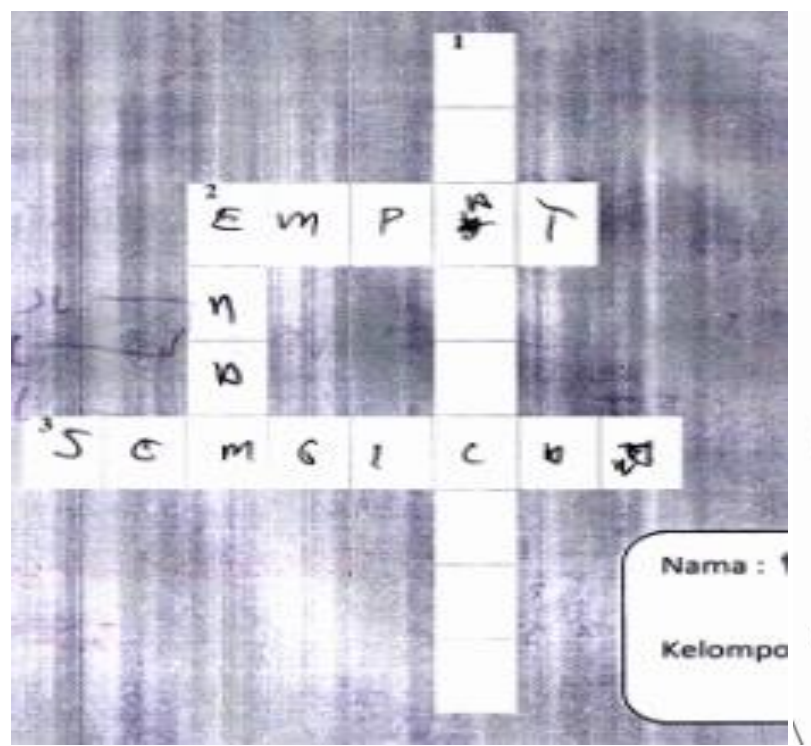

juga tidak membuatkan hasil kesimpulan akhir dari soal tersebut.

Pada pertemuan kedua, siswa sudah mulai tidak meribut dalam pembagian kelompok. Siswa sudah mulai bisa berdiskusi dengan anggota kelompok dan hasil kerja siswa sudah mulai baik. Karakteristik siswa yang diharapkan pada pertemuan kedua sudah mulai meningkat, siswa sudah mulai disiplin, tertib dan mulai bisa bekerja sama dengan anggota kelompoknya sehingga rasa tanggung jawab dan rasa ingin tahu juga muncul, tetapi kreatifitas siswa belum terlihat. Hal ini terlihat ketika guru memberikan latihan kepada masing-masing kelompok, siswa kurang teliti dalam mengerjakan latihan tanpa mendiskusikan kembali jawaban yang telah dikerjakan, sehingga menyebabkan siswa tidak optimal dalam menjawab latihan yang diberikan guru.

Mendatar :

2. Sebuah toko jaket mempunyai stok jaket berukuran small (\$), medium (M) semua ukuran tersclia dalam wama binu (B) dan lijau (H), dengan menggunakan tabel silang berapa banyak pilihan yang lersedia?

3. Jika kita akan pergi dari Jakarta ke Semarang ada 3 jalur perjalanan dan dari semarang ke Yogyzarara ada 3 jalur perjalanan. Kija scorang pecagang batik dari Jakarta hendak membeli barang dagangan di Semarang dan Yoggakarta, berapa banyakrule perjalanan pedagang tersebut!

Menurun :

1. Iwan meniliki 2 baju yang bebeda, 3 jenis dasi yang beboda dan 2 topi yang bebeda, Tentukan dengan mengyunakan diagram pothon ada beripa banyak cara iwan memilih pasangai baju, dasi dan topi?

2. Budi mempunyai 3 buah baju berwarma puth, cokelat dan biru, ia juga memiliki 2 buah celana wama hitam dan cokelat yang berbeda, dengan menggunakan cara pasangan terunt ada berapa banyak pasangan baju dan celana yang bisa dipakai budi?

Gambar 1. Contoh teka-teki silang pertemuan pertama 


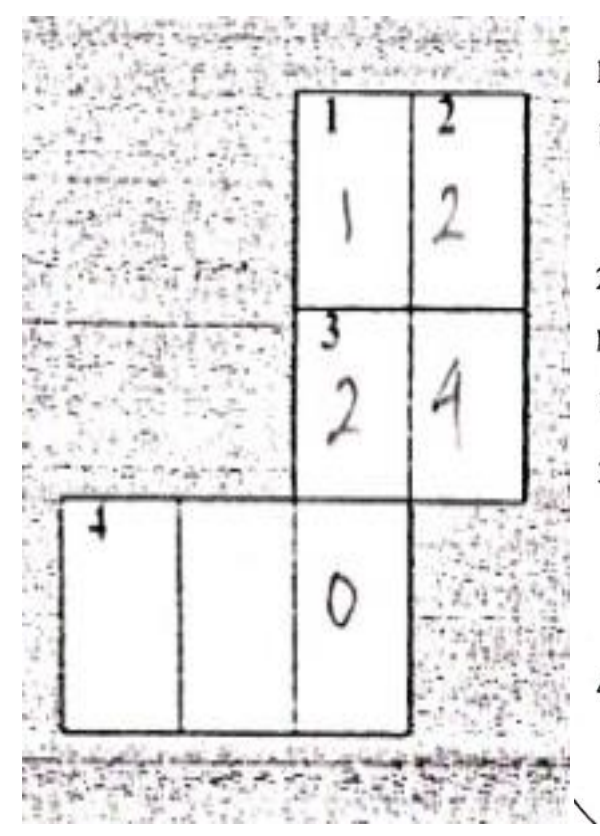

Menurun :

1. Diberikan angka $0,1,3,4,5$ dan 6 , jika ingin membuat plat nomor. Berapa banyak plat nomor kendaraan yang dapat dibuat, jika tiap no terdiri atas 3 angka yang tidak berulang?

2. Tentukanlah faktorial dari 4 !

Mendatar :

1. Tentukanlah faktorial dari $4 !-(3 !+3$ ! $)$

3. untuk membentuk pengurus baru "RW di perumahan Graha Harapan" Bekasi tersedia 3 orang calon ketua, 4 orang sekretaris, dan 2 orang calon bendahara. Dalam berapa carakah susunan pengurus yang terdiri dari seorang ketua, seorang sekretaris, dan seorang bendahara dapat dipilih dengan ketentuan tidak ada yang merangkap jabatan?

4. berapakah banyak bilangan ganjil, jika tiap bilangan terdiri dari 4 angka dan boleh ada angka yang berulang? (angka yang diberikan adalah dari soal no.Imenurun)

Gambar 2. Contoh lembar jawaban teka-teki silang siswa Pertemuan 2

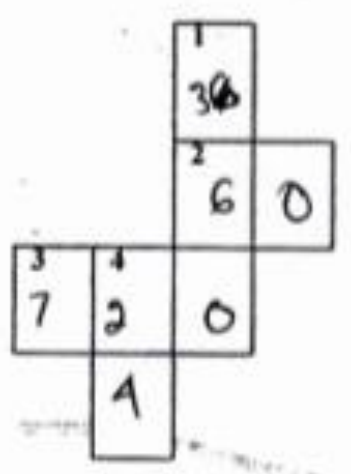

Menurun :

1. Berapa banyak susunan huruf yang dapat dibentuk dari huruf-huruf $P, A$, L, A, N dan G ?

4. Diketahui ada 5 orang yang akan menempati 5 kursi yang mengelilingi sebuah meja bundar. Berapa banyak susunan yang terjadi?

Mendatar :

2. Berapakah nilai dari $p_{3}^{5}$ ?

3. Berapa banyak kata yang terdiri atas 6 huruf yang dapat dibentuk dari kata "MELATT"?

Gambar 3. Contoh Teka-teki silang Pertemuan 3

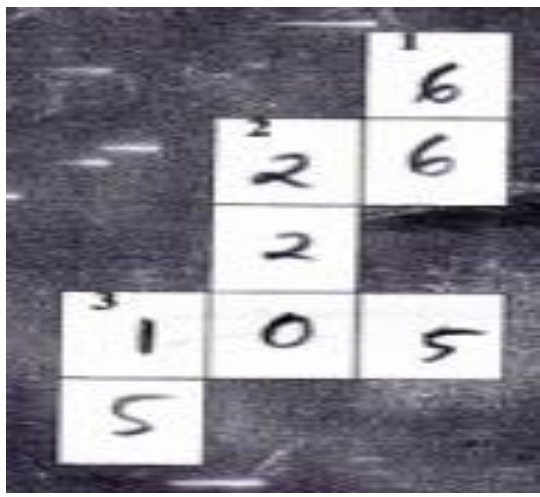

Menurun :

1. berapa banyak jabat tangan yang terjadi dalam suatu pesta yang dihadiri 12 orang ?

2. Tentukanlah nilai dari $c_{9}^{12}$ ?

3. Dari 6 orang yang terdiri dari 2 orang wanita dan 4 orang pria akan dibentuk sebuah delegasi yang beranggotakan 4 orang. Berapa banyak delegasi yang dapat dibentuk, jika setiap orang (dari 6 orang) mempunyai hak yang sama untuk dipilih sebagai anggota delegasi ?

Mendatar :

2. Diketahui himpunan $A=\{a, b, c, d, e\}$. Hitunglah banyak himpunan bagian dari $\mathrm{A}$ yang beranggotakan paling banyak 3 unsur?

3. Tentukanlah nilai dari $c_{9}^{15}$ ?

Gambar 4. Contoh lembar teka-teki silang pertemuan 4 
Pada tahap evaluasi, guru memberikan lembar teka-teki silang pada setiap siswa. Pada pertemuan kedua siswa sudah mulai terbiasa mengisi teka-teki silang. Teka-teki silang pada pertemuan kedua terlihat pada Gambar 2. Guru telah menjelaskan kepada siswa tentang cara pengisian jawaban pada teka-teki silang, siswa sudah bisa mengisi teka-teki silang tetapi masih ada teka-teki silang yang tidak terisi siswa dan ternyata setelah di cek lembar jawaban siswa masih ada siswa yang belum paham dengan materi yang telah dipelajari, karakter komunikatif siswa untuk menanyakan materi yang belum dipahami belum terlihat. Hal tersebut terlihat setelah dicek lembar jawaban siswa pada soal 1 mendatar terlihat bahwa dalam penyelesaian soal, siswa langsung menjumlahkannya, padahal seharusnya siswa mencari nilai dari masing-masing faktorial baru menjumlahkannya. Pada soal no 4 mendatar juga terlihat bahwa siswa salah dalam menyelesaikan aturan pengisian tempat, seharusnya pada kolom pertama itu angka 5 karena angka 0 tidak mungkin di awal bilangan, sedangkan pada kolom 3 itu isinya angka 6 karena 0 oleh ditengah-tengah untuk embentuk bilangan.

Pada pertemuan ketiga, siswa sudah terbiasa dengan proses pembelajaran. Dalam pembagian kelompok siswa sudah langsung duduk dikelompoknya tanpa mencari-cari lagi teman kelompoknya. Sudah adanya keinginan siswa untuk berdiskusi jawaban dengan teman-teman kelompoknya, pertemuan ketiga ini siswa sudah disiplin, tertib bekerja sama dan melaksanakan tanggung jawabnya masing-masing.
Siswa sudah bisa Mengklasifikasi objekobjek menurut sifat-sifat tertentu (sesuai dengan konsepnya), dan sudah bisa mengaplikasikan konsep atau algoritma ke pemecahan masalah. Pada tahap evaluasi, guru memberikan lembar tekateki silang pada setiap siswa. Pertemuan ketiga siswa sudah terbiasa untuk mengisi teka-teki silang dan langsung berpindah tempat duduk seperti yang diharapkan disiplin dan tanggung jawab yang tinggi. Teka-teki silang pada pertemuan ketiga terlihat pada Gambar 3.

Pada Gambar 3, siswa sudah mengisi kotak teka-teki silang semuanya dan ternyata setelah di cek lembar jawaban siswa, siswa sudah bisa mengaplikasikan konsep dalam berbagai bentuk representasi matematis. Tetapi masih ada siswa yang belum paham dengan materi yang telah dipelajari. Hal tersebut terlihat setelah dicek lembar jawaban siswa pada soal no 4 mendatar itu adalah permutasi siklis, yang rumusnya adalah $P_{s}=(N-1)$ tetapi yang dibuat siswa tersebut tidak jelas karena banyak coretan meskipun jawabannya benar.

Pada pertemuan keempat, Pada tahap evaluasi berikut contoh Teka-teki silang pada pertemuan keempat terlihat pada Gambar 4. Dalam mengisi teka-teki silang siswa sudah bisa melaksanakan dengan baik, tidak ada kekeliruan siswa dalam proses pengisian teka-teki silang pada teka-teki silang.

Berdasarkan analisis data yang telah dilakukan bahwa penerapan strategi teka-teki silang lebih baik daripada pemahaman konsep matematis siswa dengan pembelajaran konvensional. Dilihat dari proses pembelajaran di kelas 
eksperimen, siswa antusias mengikuti pembelajaran dengan adanya pengisian teka-teki silang sebagai evaluasi di akhir pembelajaran sebagai pengulangan materi, karena untuk mengisi teka-teki silang siswa harus memahami materi. Hal ini menujukkan bahwa adanya peningkatan disiplin, tertib, komunikatif, rasa ingin tahu, tanggung jawab dan kreatifitas siswa.

\section{PENUTUP}

Berdasarkan hasil analisis data dan pembahasan yang telah dikemukakan, dapat diambil kesimpulan bahwa pemahaman konsep matematika siswa dengan menerapkan strategi teka-teki silang lebih baik daripada pemahaman konsep matematika siswa yang menerapkan pembelajaran konvensional. Dengan demikian, strategi teka teki silang dapat meningkatkan pemahaman konsep siswa.

\section{UCAPAN TERIMA KASIH}

Terbitnya tulisan ini tidak terlepas dari bantuan berbagai pihak, untuk itu penulis mengucapkan terima kasih kepada UP3M STKIP PGRI Sumatera Barat dan pengelola jurnal Pelangi yang telah memberikan saran dan revisi dalam penulisan artikel ini.

\section{DAFTAR PUSTAKA}

Arikunto, Suharsimi. 2010. Dasar-Dasar Evaluasi Pendidikan. Jakarta: Bumi Aksara.

Fadjar Shadiq. 2009. Kemahiran Matematika. Yogyakarta: Depdiknas.

Khalilullah, M. 2012. "Permainan TekaTeki Silang sebagai Media dalam Pembelajaran Bahasa Arab (Mufradat)". Jurnal Pemikiran Islam, 37 (1): 15-26.

Silberman, Melvin. (2013). Active Learning 101 Cara Belajar Siswa Aktif. Bandung: Nuansa Cendikia

Sudijono, Anas (2007). Pengantar Evaluasi Pendidikan. Jakarta: PT Raja Grafindo Persada.

Suyono. (2011). Belajar dan Pembelajaran. Bandung: PT Remaja Rosdakarya

Trianto. (2007). Mendesain Model Pembelajaran Inovatif-Progresif. Jakarta: Kencana. 